\title{
From geological complexity to hydrogeological understanding using an integrated 3D conceptual modelling approach - insights from the Cotswolds, UK
}

\author{
S.H. Bricker, A.J.M. Barron, A.G. Hughes, C. Jackson \\ \& D. Peach \\ British Geological Survey, Kingsley Dunham Centre, Nottingham, UK
}

\begin{abstract}
Adequate hydrogeological conceptualisation of structurally complex fractured aquifers requires the support of detailed geological mapping and three dimensional understanding. With a geological framework in place uncertainties in hydrological understanding and irregularities in hydraulic observations may be rationalised. Using the Cotswold of southern England, which are underlain by the ooidal limestone-dominated Middle Jurassic Inferior Oolite and Great Oolite groups, 3D modelling software GSI3D and Geographical Information Systems (GIS) have been used to integrate observed hydraulic behaviours with the 3D geological framework. In this way a conceptual model is developed to assist simulation of groundwater flow and the predicted response of groundwater levels and river flows to climatic extremes. The structural and lithological complexity of the bedrock results in sub-catchments which exhibit individual hydraulic responses and a hydrogeological setting dominated by shallow rapid fracture pathways and copious spring discharge.
\end{abstract}

\section{I INTRODUCTION}

Geological maps have always been an expression of the geologist's 3D understanding of the structure and composition of the earth. In recent years 3D geological 'framework' models describing the subsurface have begun to supersede the traditional 2D geological map. Initially these tended to be of shallow superficial deposits but are increasingly of complex faulted bedrock systems (Aldiss et al., 2012). The capability for 3D geological characterisation is being driven by multi-faceted applications e.g. for engineering (Merritt et al., 2007), land-use planning (Campbell et al., 2010) and hydrogeology (Robins et al., 2005, Royse et al., 2009) such that 3D models provide the foundation for many integrated modelling approaches. Within the discipline of hydrogeology, 3D geological models have been applied to both hydrogeological and groundwater modelling e.g. for permeability mapping, as a framework for risk screening tools (Marchant et al., 2011), to delineate aquifer volumes and boundaries within groundwater flow models and to visualise model outputs (Wang et al., 2010). A detailed 3D geological model may also be applied where geology is structurally complex. The model supports hydrogeological conceptualisation where uncertainties 
in hydrological understanding and irregularities in hydraulic observations may be rationalised (Royse et al., 2010).

The Jurassic sequence of the Cotswolds, in which lie the headwaters of the River Thames, is complex both in terms of lithology, where units are thin and laterally variable, and structure. The strata are highly fractured, disrupted by steeply dipping normal faults and cambering and dissected by deep river valleys. By resolving the geological configuration in $3 \mathrm{D}$ it is easier to visualise and understand the hydrogeology and subsurface flow processes.

The limestones of the Middle Jurassic within the Cotswolds form a principal aquifer. Licensed groundwater abstraction nears $50 \mathrm{Ml} / \mathrm{d}$ much of which is used for public water supply serving 250000 people. Non-consumptive abstractions for fish farming and mineral workings are also common within the region. Base flow derived from the Jurassic sequence of the Cotswolds is reputed to have sustained river flows further downstream within the Thames basin during recent droughts (e.g. 2004-2006) (pers. comm. Jones, 2011). Rivers draining the Cotswolds have high base flow indices (BFI) all year round; the BFI for the River Churn at Cirencester varies from 0.71-0.89, while the BFI for the River Coln at its downstream gauging station varies from 0.890.98 seasonally (CENTRE FOR ECOLOGY AND HYDROLOGY, 2012). Base flow within the River Thames downstream of the Cotswolds remains above $50 \mathrm{Ml} / \mathrm{d}$ during a typical summer recession and exceeds $25 \mathrm{Ml} / \mathrm{d}$ during some of the more extreme drought periods (period of record 1992-2008) (CENTRE FOR ECOLOGY AND HYDROLOGY, 2012). However, the sustainable management of water resources in the Cotswold area is challenging particularly under low flow conditions where groundwater resources are already fully allocated (ENVIRONMENT AGENCY, 2007). Public water supply licences have been subject to review, both within the Cotswolds and further downstream in the Thames basin, in an effort to reduce the impacts of groundwater abstraction on river flows. Meanwhile climate change predictions (UK Climate Impacts Programme) suggest reductions in summer river flows typically between 20-50\% by 2050 within the Thames Basin (ENVIRONMENT AGENCY, 2012).

This chapter describes the integration of hydrogeological data within a geological framework model as a means to further our understanding of the catchment hydrogeology and controls on groundwater flow. The mid-Jurassic series of the Cotswolds is used as a case study. Using the 3D modelling software and Geographical Information Systems (GIS) the influence of lithology and structure on groundwater flow and discharge processes is examined along with the importance of perched water tables and shallow flow paths for river base flow contribution. The relationship between the Middle Jurassic Great and Inferior Oolite limestone successions controls the potential for hydraulic interconnectivity between the Great Oolite and Inferior Oolite aquifers. The refined conceptual model provides a basis for onward numerical simulation of groundwater flow to assess the response of hydrological system to climate change and extreme events.

\subsection{D GEOLOGICAL MODELLING}

A 3D platform for geological mapping using the Geological Surveying and Investigation in three dimensions tool (GSI3D, (OInsight $\mathrm{GmbH}$ ) has been available to geologists since the late 1990s. Its successful uptake since then is largely due to the intuitive 


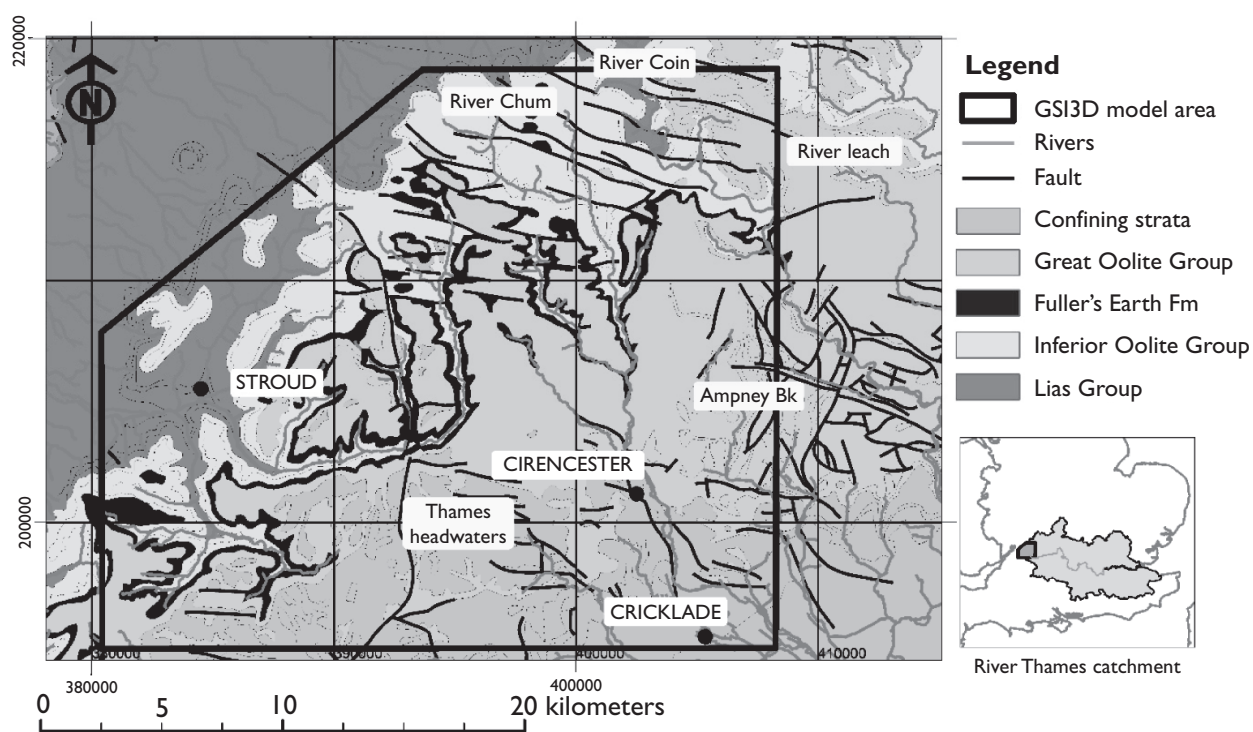

Figure 6.I Location of the study area showing extent of the Cotswolds 3D geological model and 250k mapped geology with location of faults and drainage network. The position of the River Thames catchment (grey) and study area (green) is indicated on the smaller location map. Contains Ordnance Survey data (C) Crown Copyright. (See colour plate section, plate I7).

geologically-based methodology that allows the incorporation of a geologist's expert knowledge (Kessler et al., 2009). This approach is similar to 3D geology methodologies adopted elsewhere (e.g. Kaufmann \& Martin, 2008). Such 3D models are able to encapsulate the implicit and tacit knowledge from the mapping geologist and convey the degree of uncertainty in the depth profile which is otherwise absent in the interpretation of 2D maps and cross-sections by the non-expert viewer (Howard et al., 2009). The end product from such models may, therefore, be viewed as a geological interpretation as opposed to a modelled output. This more qualitative knowledgedriven approach has advantages over interpolation-based software packages, where geological data are unevenly distributed and the complexity of the geological structure requires significant extrapolation (Kessler et al., 2009).

The confidence in GSI3D and other similar modelling approaches is manifest in the wide range of applications and in the variety of end-users which includes geological surveys, regulators, the water industry and local government (Kessler et al., 2009). For the Cotswolds the environmental regulator provided the original impetus for the development of a 3D geological framework model to assess groundwater catchment divides for better groundwater resource management (Maurice et al., 2008). Recognising the complexity of the geological setting, and the implications for successful resource management the original 3D framework model was refined to provide the basis for an enhanced hydrogeological conceptual model.

The 3D geological model developed in GSI3D covers some $600 \mathrm{~km}^{2}$ of the Cotswolds between Cricklade in the south-east and Gloucester in the north-west (Figure 6.1). 
While the model does not provide complete coverage of the Cotswolds the lithological sequence and geological features present within the study area are representative of the wider Cotswolds area. Inferences made with respect to the integration of the 3D geology with hydrogeological characteristics are, therefore, more widely applicable. The 3D geology was modelled by the regional geologist using 139 borehole records within 42 cross-sections with a combined length of nearly $600 \mathrm{~km}$ in conjunction with digital surface 1 bedrock maps at the 1:50 000 scale. 35 bedrock units from the Whitby Mudstone Formation at its base through to the Oxford Clay Formation are incorporated into the 3D model with strata mapped at the formation or member scale where appropriate. The model also includes approximately 80 faults for which the geological displacements have been resolved.

The model provides 3D surfaces for the base of each of the geological units, synthetic cross-sections and information about fault displacements and river bed geology. It is the integration of this geological information with hydrogeological datasets, both within the GSI3D model and within inter-operable software packages such as GIS that considerably advances the hydrogeological conceptualisation.

\subsection{GEOLOGY}

The bedrock geological strata of the Cotswolds are of Jurassic age and comprise an alternating sequence of limestones and mudstones which were laid down in a shallow marine environment (Sumbler et al., 2000). The geological sequence of the study area is summarised in Table 6.1 and mapped in Figure 6.1. The Early Jurassic age was marked by a period of global sea-level rise during which the predominant deposition was of thick marine mudstones of the Lias Group. Following global sea-level recession, most of the Mid Jurassic is characterised by relatively modest changes in sea level (both eustatic and related to regional uplift or subsidence) and moderate subsidence of the shelf areas (Barron et al., 2012). Consequently, many of the formations are difficult to map at regional scales being relatively thin, and laterally variable and impersistent especially where facies belts have migrated laterally through time (Barron et al., 2012). This was when the ooidal limestones of the Inferior and Great Oolite Group aquifers were laid down. These two aquifer units are separated by the Fuller's Earth Formation, a predominantly land-derived silicate mud deposit which marks a brief period of subsidence (Barron et al., 2012). Sea-level rise and coastal retreat during the late stages of the Jurassic age led to the widespread deposition of silicate mudstones of the Kellaways and Oxford Clay formations which serve to confine the Great Oolite aquifer.

The study area comprises rolling upland sloping gently to the south-east towards the upper reaches of the River Thames and dissected by incised river valleys. Regionally the bedrock dips about $1^{\circ}$ to the south-south-east, although locally dips may reach $5^{\circ}$ or more mainly as a result of faulting (Sumbler et al., 2000). The alternating sequence of permeable limestones and low permeability mudstones gives rise to significant spring discharge and has also led to widespread cambering along escarpments and hill slopes in which (largely under periglacial conditions) the weaker mudstone units have deformed and squeezed out causing disruption in the overlying more competent limestones (Sumbler et al., 2000). The fractured limestone aquifers of the midJurassic strata are of most hydrogeological interest. 
Table 6.I Geological sequence present within the study area along with the aquifer classification as defined by the environmental regulator; adapted from Neumann et al. (2003).

\begin{tabular}{|c|c|c|c|c|}
\hline Age & \multicolumn{2}{|c|}{ Lithostratigraphy } & Rock Type & $\begin{array}{l}\text { Aquifer } \\
\text { classification }\end{array}$ \\
\hline 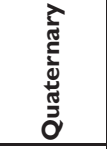 & \multicolumn{2}{|c|}{$\begin{array}{l}\text { Alluvium } \\
\text { River terrace deposits }\end{array}$} & $\begin{array}{l}\text { Variable limestone gravel, loam and clay } \\
\text { Mainly limestone gravel }\end{array}$ & $\begin{array}{l}\text { Secondary } \\
\text { Secondary A }\end{array}$ \\
\hline 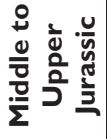 & \multicolumn{2}{|c|}{$\begin{array}{l}\text { Oxford Clay Formation } \\
\text { Kellaways Formation }\end{array}$} & $\begin{array}{l}\text { Grey mudstone } \\
\text { Grey mudstone overlain by fine-grained sand }\end{array}$ & $\begin{array}{l}\text { Unproductive } \\
\text { Unproductive }\end{array}$ \\
\hline 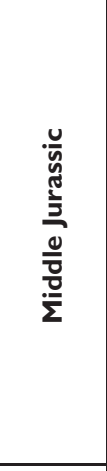 & $\begin{array}{l}\text { Great Oolite Group: } \\
\text { Cornbrash Formation } \\
\text { Forest Marble Formation } \\
\text { White Limestone Formation } \\
\text { Hampen Formation }\end{array}$ & $\begin{array}{l}\text { Oolite Group: } \\
\text { brash Formation } \\
\text { t Marble Formation } \\
\text { e Limestone Formation } \\
\text { en Formation } \\
\text { on Limestone Formation } \\
\text { 's Earth Formation } \\
\text { Oolite Group: } \\
\text { ton Limestone Formation } \\
\text { Limestone Formation } \\
\text { p Limestone Formation }\end{array}$ & $\begin{array}{l}\text { Rubbly, shell-detrital limestone } \\
\text { Mudstone with beds of shell-detrital, ooidal } \\
\text { limestone } \\
\text { Limestone with minor mudstone beds } \\
\text { Sandy and ooidal limestone with mudstone } \\
\text { beds } \\
\text { Shell-detrital ooidal limestone } \\
\text { Grey mudstone with limestone beds }\end{array}$ & $\begin{array}{l}\text { Secondary A } \\
\text { Principal/ } \\
\text { Secondary A } \\
\text { Principal } \\
\text { Principal } \\
\text { Principal } \\
\text { Unproductive } \\
\text { Principal } \\
\text { Principal } \\
\text { Principal }\end{array}$ \\
\hline 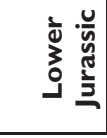 & $\begin{array}{l}\text { Lias G } \\
\text { Bridp } \\
\text { Whith }\end{array}$ & $\begin{array}{l}\text { roup (part): } \\
\text { ort Sand Formation } \\
\text { by Mudstone Formation }\end{array}$ & $\begin{array}{l}\text { Sandy mudstone and fine-grained sandstone } \\
\text { Mudstone with limestone beds at base }\end{array}$ & $\begin{array}{l}\text { Principal } \\
\text { Unproductive }\end{array}$ \\
\hline $\begin{array}{l}\text { Principal } \\
\text { Seconda } \\
\text { Unprodu }\end{array}$ & $\begin{array}{l}\text { ry A } \\
\text { active }\end{array}$ & $\begin{array}{l}\text { Geological units with high in } \\
\text { Permeable layers capable of } \\
\text { Rock layers or superficial } \\
\text { supply or river base flow. }\end{array}$ & $\begin{array}{l}\text { rgranular and/or fracture permeability. } \\
\text { upporting water supplies at a local rather than strateg } \\
\text { posits with low permeability that have negligible si }\end{array}$ & $\begin{array}{l}\text { gic scale. } \\
\text { gnificance for water }\end{array}$ \\
\hline
\end{tabular}

The Middle Jurassic succession comprises the Great Oolite and Inferior Oolite groups. For the purpose of this, and previous studies (e.g. Maurice et al., 2008; Royse et al., 2010) the lower aquifer comprises the Inferior Oolite Group, composed entirely of limestone, and the fine-grained sandstone beds of the underlying Bridport Sand Formation (uppermost Lias Group).The upper aquifer is comprised of a succession of limestone strata from the upper part of the Fuller's Earth Formation, through to the limestone beds at the base of the Forest Marble Formation (all part of the Great Oolite Group; Table 6.1; Figure 6.1). Colloquially, these are referred to as the Great Oolite and Inferior Oolite aquifers, which range in thickness from 32 to $55 \mathrm{~m}$ and 30 to $80 \mathrm{~m}$ respectively. The mudstone beds of the intervening Fuller's Earth Formation are between 20 and $50 \mathrm{~m}$ thick and the Whitby Mudstone Formation underlying the Bridport Sand comprises 30 to $95 \mathrm{~m}$ of low permeability mudstone. The upper part of the Forest Marble is dominated by silicate mudstone beds, and although these include 
lenses of limestone, and are capped by the thin limestone succession of the Cornbrash Formation, they form an effective confining layer above the Great Oolite aquifer, together (in the extreme south-east) with the thick mudstone-dominated succession of the Kellaways and Oxford Clay formations, overlying the Cornbrash.

The limestone units which dominate these aquifers range in lithology from crossbedded coarse-grained shelly and ooidal to fine-grained and sandy types with subordinate and laterally impersistent mudstone layers (Barron et al., 2012). In terms of their gross lithologies the Great Oolite and Inferior Oolite aquifers are similar although the Great Oolite contains a significant proportion of interbedded mudstone. The aquifers units are highly dissected by fracturing which occurs both along and across bedding planes and by faulting where displacements of over $50 \mathrm{~m}$ cause the juxtaposition of different geological units (Maurice et al., 2008). The fracture control on surface water drainage is also evident with river networks often aligned with major lineaments.

\subsection{HYDROGEOLOGY OF THE MID-JURASSIC GREAT OOLITE AND INFERIOR OOLITE AQUIFERS}

The limestone-dominated Great Oolite and Inferior Oolite aquifer units are of principal importance for groundwater resources. Several investigations into the hydrogeology of these aquifers were completed in the 1980s and 1990s, driven largely by groundwater resource exploitation and accompanying legislation. The investigations invariably focussed on a specific local issue or aquifer unit e.g. the Great Oolite (Rushton et al., 1992) and only rarely (Rushton et al., 1992) appear in the peer-reviewed literature. A notable exception is a review of the hydrogeochemistry of the Jurassic limestones provided by Morgan-Jones \& Eggboro (1981). Findings from these investigations are presented in Maurice et al. (2008) while the hydrogeology is summarised in Allen et al. (1997) and Neumann et al. (2003).

The limestones of the Great Oolite and Inferior Oolite Groups are generally wellcemented with low inter-granular permeability and low storage potential (Morgan-Jones \& Eggboro, 1981). Aquifer productivity derives from secondary deformation with rapid groundwater flow occurring along fracture pathways. Karstic flow, where fractures are enhanced by dissolution, is also suggested (Allen et al., 1997). The combination of low storage and high transmissivity means that both aquifers are 'flashy' with large seasonal variations in groundwater levels and a rapid response to rainfall (Rushton et al., 1992). Shallow pathways which provide rapid groundwater flow to rivers prior to the recovery of aquifer storage are evident as well as deeper pathways for groundwater which recharge the confined aquifer over longer timescales (Rushton et al., 1992). While separated from each other by the mudstones of the Fuller's Earth Formation, there are places where the Great Oolite and Inferior Oolite are in hydraulic continuity as a result of faults which connect the aquifers (Maurice et al., 2008). The impact of faulting and fracturing on groundwater systems also extends to cross-catchment groundwater flow (Maurice et al., 2008) and migrating and intermittent river reaches where rivers recharge the aquifer (Rushton et al., 1992) as well as limiting the extent of drawdown due to abstraction (Morgan-Jones \& Eggboro, 1981). Where information about the geological structure and faulting in the third dimension is often limited, particularly for confined or concealed aquifers, 3D geological models may be used to interrogate the detailed geology and explore the relative importance of structure versus lithology on groundwater flow. 


\subsection{Integrating hydrogeological data with geology models}

The integration of hydrogeological data with the geological interpretation has always been essential for the development of conceptual and numerical groundwater models. However the development of a 3D geological framework model brings advantages by capturing more explicitly the geologist's structural interpretations such that the geology is not oversimplified in subsequent process modelling. Some novel approaches to integrate spatial geology and hydrogeology datasets in a 3D model for both visualisation and scientific understanding have been explored within this project and are summarised in Table 6.2.

Table 6.2 Description of the hydrogeological datasets integrated with the geological framework model.

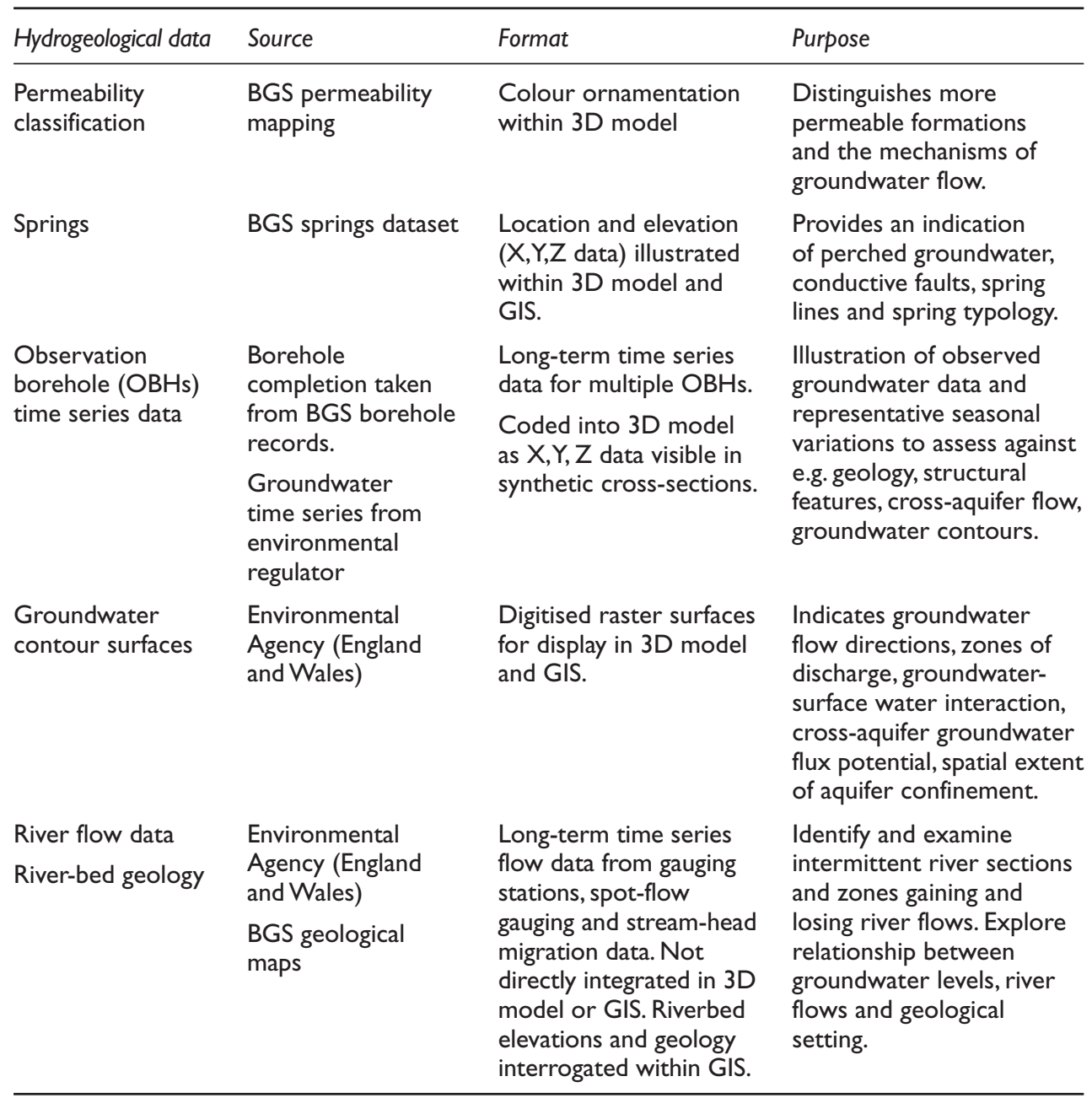




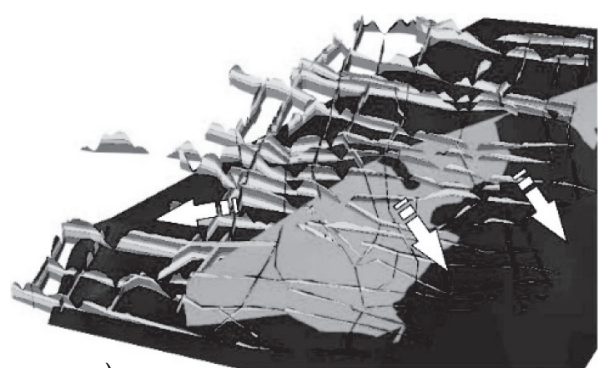

a)

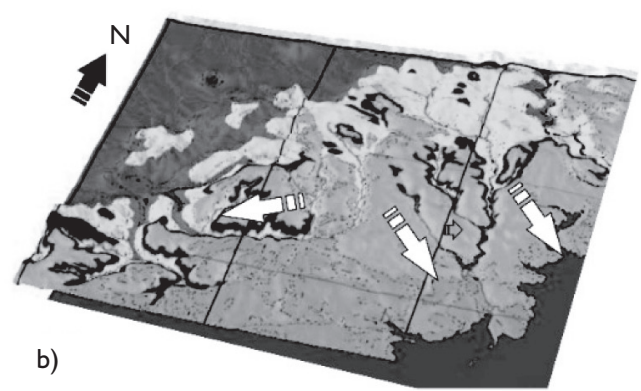

Figure 6.2 Outputs from the GSI3D model showing a) the geological cross-sections with maximum groundwater level surfaces for the Inferior Oolite aquifer (dark blue) and the Great Oolite aquifer (light blue), and; b) the mapped geology at surface ( $1: 250000$ scale) draped over the digital terrain model along with the groundwater level surface to highlight where artesian groundwater levels exist in the Inferior Oolite aquifer under maximum groundwater level conditions (dark blue). White arrows highlight the regional groundwater flow direction; note the catchment divide between the River Thames to the east and the River Severn to the west. Contains Ordnance Survey data (C) Crown Copyright. (See colour plate section, plate 18).

\subsubsection{Interaction between the Great Oolite and Inferior Oolite aquifer}

The Great Oolite and Inferior Oolite aquifers are hydraulically independent aquifer units with different water table elevations despite evidence of localised connectivity e.g. via faults (Maurice et al., 2008). To gain an initial overview of the aquifer systems, groundwater level contour surfaces for maximum and minimum groundwater level conditions, for each of the aquifers were imported into the geological model and viewed in 3D (Figure 6.2). Under maximum groundwater level conditions in the west of the model area groundwater levels in the Inferior Oolite are below those of the Great Oolite i.e. potential downward flow of groundwater between the aquifers while to the east the groundwater levels in the Inferior Oolite aquifer are above those of the Great Oolite hence a potential upward flow of groundwater. By introducing a digital terrain model (DTM) as a capping surface to the geology model the interaction of the Great Oolite and Inferior Oolite water tables with surface water systems is apparent and artesian groundwater levels can be seen (Figure 6.2). Under minimum groundwater level conditions, the Inferior Oolite aquifer appears to contribute only to the River Coln, a tributary of the River Thames (Figure 6.1). Under high groundwater level conditions, there again appears to be greater contribution from the Inferior Oolite aquifer within the upper reaches of the River Coln than within the River Churn, another tributary of the River Thames (Figure 6.1). This may suggest that groundwater contributions to the headwaters of the River Churn are from perched springs following shorter pathways elevated above the main aquifer as a result of well-developed fracture zones. The more pronounced accretion in river flows down the valley of the River Coln, compared with the River Churn, where initial spring flow contribution in the headwaters appears to be lost further downstream, might support 

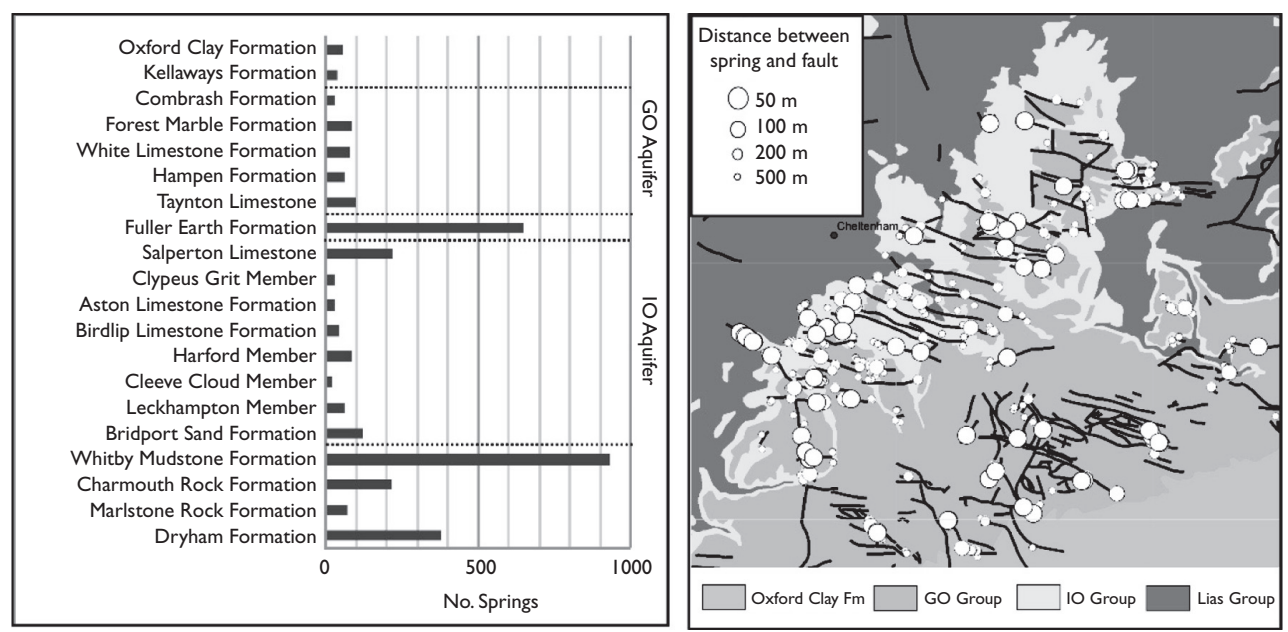

Figure 6.3 Stream head migration for the Ampney Brook during 1994-2010 is shown along with groundwater level variations within a Great Oolite observation well. Four locations to which the Ampney Brook migrates to are identified. The surface and sub-surface geology at each of these locations is shown. Groundwater level and river source location data () Environment Agency copyright and/or database rights 2012. All rights reserved. (See colour plate section, plate 19).

this hypothesis (Parades, 2012). The interaction of the Great Oolite aquifer with surface water streams appears to be more restricted under maximum groundwater level conditions. However, there is an apparent contribution from the Great Oolite aquifer at the head of the River Thames where several springs emanate and within the lower sections of the Ampney Brook (Figures 6.1 and 6.3). There may also be some contribution from the Great Oolite aquifer at its boundary with the Inferior Oolite aquifer within in the valley of the River Churn where the channel is more heavily incised than its neighbouring tributaries.

The presence and effect of faulting on the aquifer units is not always obvious, particular where they are confined. As a result groundwater contour maps constructed within a 2D mapping environment, albeit with hydrogeological expertise, are unlikely to encapsulate satisfactorily the 3D geological setting, the role of faults in compartmentalisation of the aquifer and the potential cross-connection of aquifers. Inspection of the fault sections within the GSI3D model suggests that while throws may on occasion be large (over $50 \mathrm{~m}$ ) there are actually very few instances within the area where the Inferior Oolite or Great Oolite are juxtaposed as a result of the displacement. This implies that groundwater flow between the two aquifer systems is a function of conductivity along the fault zone. Viewing existing groundwater contour maps in combination with groundwater levels observed in boreholes within a 3D geological model resolves groundwater level contours around the 3D geology and fault networks and for example, faults are categorised into those which are conductive and those which act as barriers. 


\subsubsection{Structural control on hydrogeology}

Morgan-Jones \& Eggboro (1981) suggest that groundwater flow is less controlled by the stratigraphy and more by the structure yet spring lines occur at the junction of specific stratigraphical units such as the Fuller's Earth Formation or are associated with marl bands within units (Allen et al., 1997). To assess the influence of structure versus lithology further, spring locations were correlated with a) mapped geological units using the digital geological map at the 1:50 000 scale (DiGMapGB50), and b) mapped faults all within a GIS format. Correlating springs with stratigraphical units yields predictable results which are in keeping with previous investigations (Morgan-Jones \& Eggboro, 1981). For example numerous springs are observed at the base of Great Oolite aquifer at its junction with the Fuller's Earth Formation and at the base of the Inferior Oolite aquifer at its junction with the underlying Lias mudstones. Spring discharge is also coincident with the Hampen Formation, an interbedded limestone and marl unit of the Great Oolite and the Harford Member, a sand and clay unit within the Birdlip Limestone Formation of the Inferior Oolite (Figure 6.3).

To the north of the area, coincident with the outcrop of the Inferior Oolite aquifer, is a strong association between springs and mapped faults (Figure 6.4). These springs are not rising along faults under artesian pressure, they are perched and discharge at an elevation above the main water table within the Inferior Oolite. Enhanced deformation and higher fracture density within the limestone units around the fault zone offers a plausible explanation for the discharge of groundwater in the shallow zone emanating at the perched springs. There are faults located on the outcrop of the Great Oolite aquifer, to the east of the area, within the lower Coln valley (Figure 6.1) and adjacent River Leach catchment which don't have any springs associated with them despite expected artesian groundwater conditions in the Inferior Oolite aquifer. Either the throws on the faults in this area are insufficient to provide a pathway for artesian Inferior Oolite groundwater to reach surface or that any upward flow of groundwater from the Inferior Oolite aquifer contributes to the overlying Great Oolite aquifer which itself is not artesian and is expected to have available storage during low flow periods. The intermittent nature of flows in the River Leach along this faulted section offers further evidence that the Great Oolite aquifer in this area becomes depleted during summer periods where river flows are lost to Great Oolite aquifer storage.

The influence of structure on river flows is further illustrated by examining stream-head migration of the rivers along their intermittent sections. Using the Ampney Brook (Figure 6.1) as an example (Figure 6.3) we see that there are four principal locations to which the Ampney Brook rises to, all of which are coincident with geological features or the presence of springs; the first lies on a mapped fault; the second occurs at the boundary of the Hampen Formation with the overlying White Limestone Formation; the third occurs at the boundary of the Great Oolite limestones with the overlying confining layer of the Forest Marble mudstones; the fourth occurs at the confluence of a dry valley with the main channel of the Ampney Brook. An association between stream-head migration and groundwater levels in the Great Oolite aquifer is also evident, while the additional influence of groundwater abstraction from the Great Oolite aquifer has also observed (James, 2011).

Further information about the geological controls on the hydrological observations may be elucidated by viewing the river flow accretion profiles in combination 

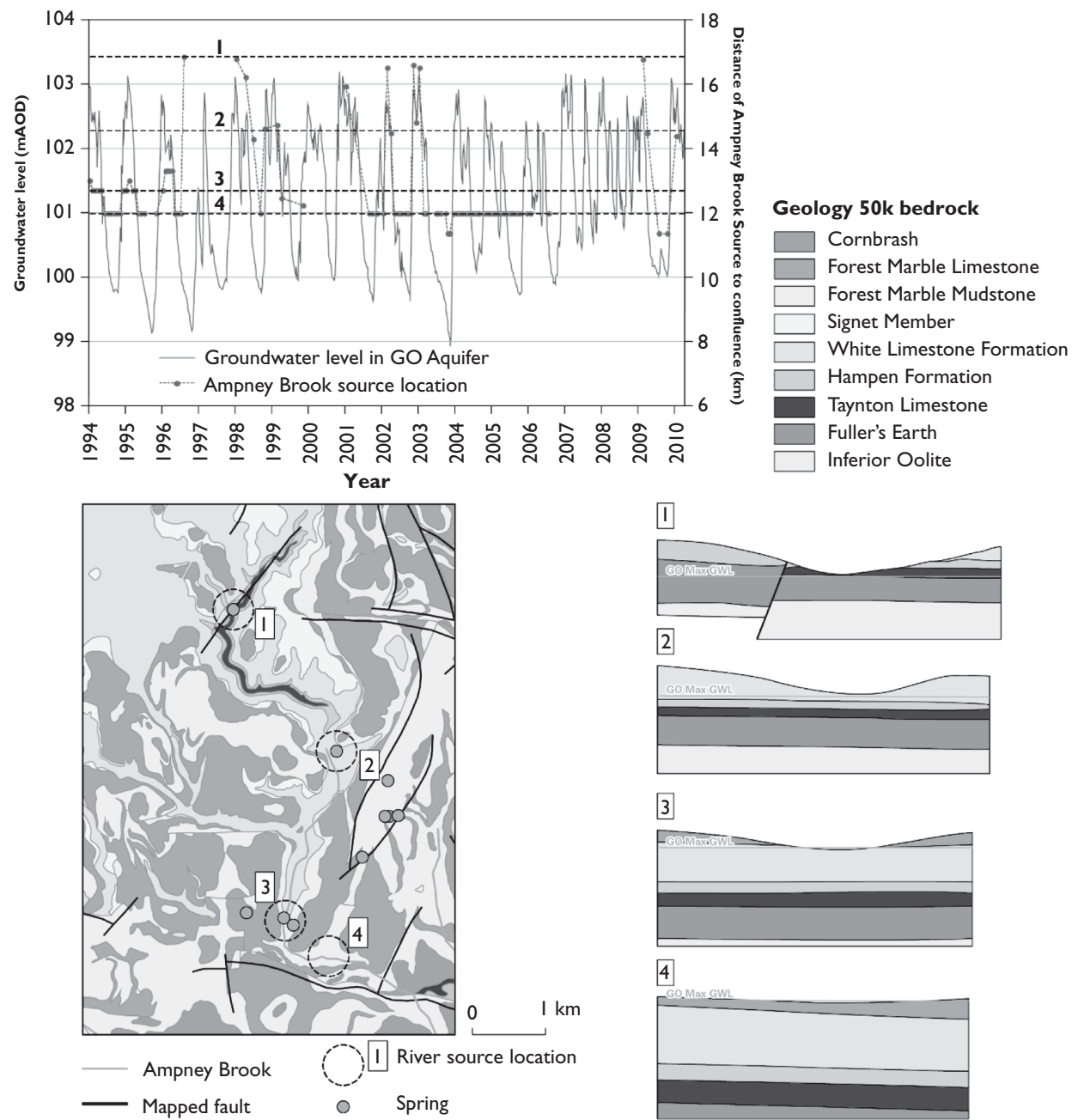

4

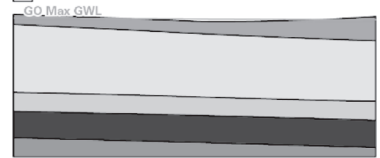

Figure 6.4 The number of springs associated with each of the geological unit mapped at surface ( $\mathrm{I:50}$ 000), and; the extent to which springs are associated with mapped fault. (See colour plate section, plate 20).

with the river bed geology extracted from the GIS and geological profiles across river sections derived from GSI3D. For example, river flow accretion profiles along the River Churn exhibit a reduction in flow over both the Inferior Oolite and the Great Oolite limestones with the river recharging the underlying aquifer (Figure 6.5). Meanwhile there are significant increases in river flows over the mudstone units of the Lias Group, Fuller's Earth Formation and the upper Jurassic clays, reflecting the reemergence of groundwater at the boundary of these less permeable units with the more permeable limestones at well-developed spring lines. The significance of the activation of these spring lines and groundwater discharge points as aquifer storage 


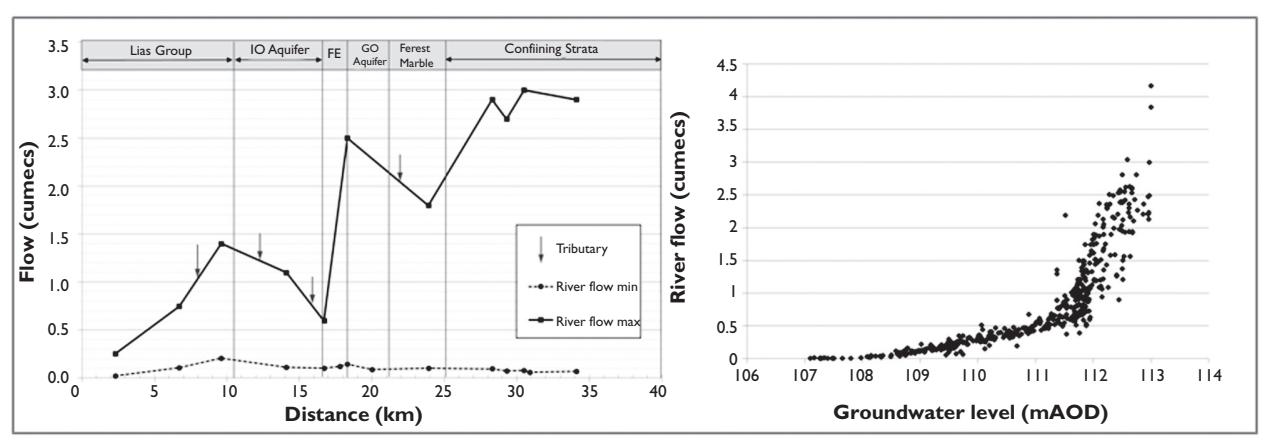

Figure 6.5 Flow accretion profile for the River Churn showing the influence of bedrock geology on gaining and losing river sections and; the relationship between groundwater levels in the Great Oolite at observation well SP00/I42 and flows in the River Churn at the same location. River flows measured manually at spot locations and reported to an accuracy of one litre per second. Groundwater level and river flow data (C) Environment Agency copyright and/or database rights 2012 . All rights reserved.

is replenished is evident when correlating river flows in the Churn at Cirencester (Figure 6.1) against groundwater levels within the Great Oolite aquifer at a nearby observation well (SP00/142). A groundwater level threshold is observed, controlled by the discharge elevation of the spring line, above which increases in groundwater level are small compared to increases in river flow (Figure 6.5).

\subsubsection{Conceptual understanding using spring type}

Spring discharge, whether stratigraphically or structurally controlled, exerts a strong influence on the hydrological observations within the Cotswolds and characterisation of the spring discharge mechanisms may be used to define broad hydrogeological domains (Figure 6.6). For example, in areas where perched groundwater is present and shallow and rapid pathways for groundwater discharge are expected: conversely areas can be defined where groundwater discharge, via springs, occurs at the intersection of the main aquifer water table. A simple approach is adopted whereby the ground elevation of the spring is compared with groundwater level elevations in both the Great Oolite and the Inferior Oolite aquifers. Where the spring elevation lies well above the groundwater level elevation we consider the spring to be perched. Where there is good agreement between the spring elevation and the groundwater level in one of the aquifers there is likely to be potential groundwater discharge from that aquifer unit. Where there is good agreement between the spring elevation and the groundwater level in both of the aquifers groundwater discharge from either or both aquifer units is plausible and the two aquifers may be in hydraulic continuity at that point. The rules used to define the hydrogeological domains are described in Table 6.3. The hydrogeological domains may be verified using more localised understanding derived 


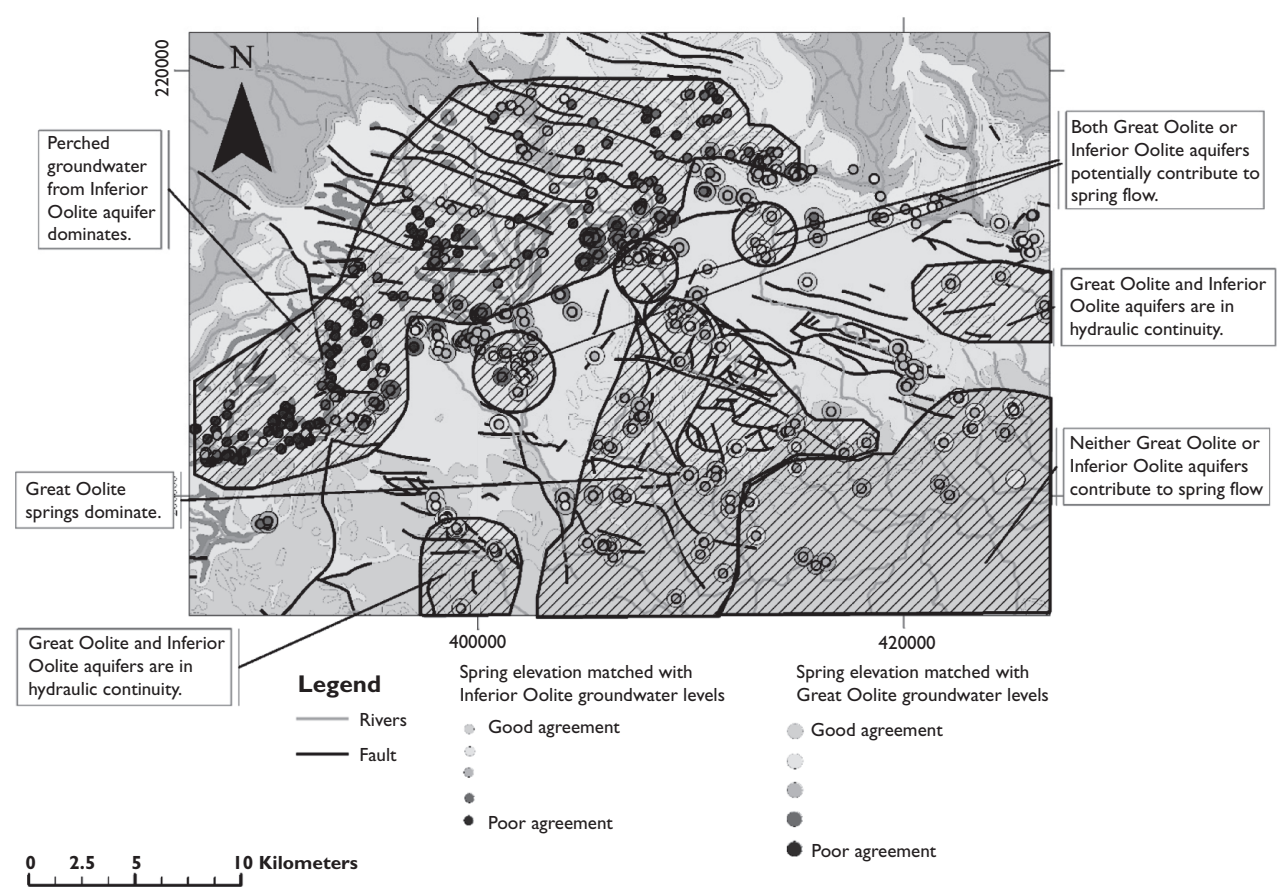

Figure 6.6 Hydrogeological domains for the Cotswold aquifers derived using the relationship between spring elevation and groundwater levels within the underlying Great Oolite and Inferior Oolite aquifer as an indicator of groundwater discharge processes and aquifer inter-connectivity. Contains Ordnance Survey data (C) Crown Copyright. (See colour plate section, plate $2 I$ ).

Table 6.3 Hydrogeological significance of elevation agreement between spring elevations and groundwater level elevations.

\begin{tabular}{ll}
\hline Elevation agreement & Hydrogeological significance \\
\hline $\begin{array}{l}\text { The spring elevation shows no correlation with } \\
\text { groundwater levels in either the Great Oolite } \\
\text { or Inferior Oolite aquifer. }\end{array}$ & $\begin{array}{l}\text { The spring is discharging groundwater from a } \\
\text { different aquifer unit OR the spring is perched } \\
\text { above the main water table. }\end{array}$ \\
$\begin{array}{l}\text { The spring elevation is correlated with the } \\
\text { groundwater level in one of the aquifers. }\end{array}$ & $\begin{array}{l}\text { The Great Oolite and Inferior Oolite aquifers } \\
\text { are hydraulically independent at this location } \\
\text { with different groundwater levels AND there } \\
\text { are perched springs associated with upper }\end{array}$ \\
& $\begin{array}{l}\text { aquifer OR artesian springs associated with the } \\
\text { lower aquifer. }\end{array}$ \\
$\begin{array}{l}\text { The spring elevation correlates with groundwater } \\
\text { levels in both the Great Oolite and Inferior }\end{array}$ & $\begin{array}{l}\text { The Great Oolite and Inferior Oolite are in } \\
\text { hydraulic continuity at this location OR the } \\
\text { Oolite aquifer. }\end{array}$ \\
& Oolite groundwater level is coincidental.
\end{tabular}


from the 3D geological model and groundwater observations or from anecdotal information, for example throws on the faults may be examined in the 3D geological model to confirm or exclude the potential cross-aquifer connection.

\subsection{DISCUSSION AND CONCLUSIONS}

The accuracy of a 3D geological framework model may be constrained by both the particular approach and the quality of data available so care must be taken not to over-interpret the results. For example, much of our understanding of an aquifer system derives from groundwater contour maps; while compiled using high quality groundwater level data and expert judgement they were delineated using a 2D approach and interrogation of these contours in 3D may show them to be deficient in some areas. Equally important, the 3D geology is an interpretation and is limited by the availability, spatial density and quality of borehole logs and the accuracy and scale of geological mapping available. Thus the integration of geological and hydrogeological information should be viewed as an iterative process where new observations may inform understanding developed in the other.

The 3D geological framework is built by extrapolation and interpolation from and between point information to produce an upscaled more generalised understanding. The same is true of developing a groundwater or hydrogeological conceptual model in three dimensions. Point observations are taken and interpolated spatially to reveal spatial trends. When these approaches are integrated both the hydrogeological model and the 3D geological framework are subjected to a new set of constraints that must be resolved. Local hydrogeological detail can be examined against the background of the geological setting to reveal errors or hopefully agreement in the datasets and conceptual understanding. The success of this process, demonstrated here in the Cotswolds lies in the enhanced ability to resolve many of the detailed hydrological observations with what can be elucidated from the 3D geology. This results in the refinement of a broader conceptual understanding. In this case, for example, such that hydrogeological domains may be delineated over a wider area. This ability to use detailed local information and data to refine conceptual understanding at the greater scale, i.e. from local to subcatchment to catchment and even regional level, introduces a level of refinement and new science hitherto not available.

In the Cotswolds this approach has allowed a multi-scale approach by using a combination of 3D geological framework modelling, geospatial hydrogeological data and information manipulation in this integrated fashion. At the local scale the model was used to understand specific hydraulic observations such as spring emergence at fault zones but also more broadly to assess catchment groundwater flow and hydrogeological domains. There are significant geological controls on the hydrogeological characteristics, exerted by both the stratigraphy and by the structure. The limestone aquifer units being highly deformed by intense fracturing and faulting, provide shallow pathways in the unsaturated zone for rapid groundwater discharge to springs elevated above the main zone of aquifer storage. The highly fractured unsaturated zone around incised river valleys is equally important for directed aquifer recharge and river losses. While fracturing provides the dominant control on aquifer recharge and groundwater conveyance, groundwater discharge is often controlled by the presence 
of mudstones in the stratigraphical sequence along which prominent spring lines have developed. Faulting also appears to provide a localised mechanism for groundwater discharge and the exchange of groundwater between the two aquifers.

While many of the observations about the Great Oolite and Inferior Oolite aquifers are in agreement with previous investigations, the 3D process demonstrates more clearly the relationship between the 3D geology and how that gives rise to the hydraulic responses observed and the hydrogeological conceptual model has been considerably improved on a local catchment scale.

\section{ACKNOWLEDGEMENTS}

The authors thank NERC for funding this work within the Changing Water Cycle Hydrological Extremes and Feedbacks (HydEF) project and members of the HydEF project team for their advice. We also thank the reviewers for their constructive comments, Holger Kessler and Ian Cooke for their support with the 3D geological modelling and Henry Holbrook for the illustrations. The contributions of visiting MSc students Katy James, Cristian Parades and Fiona Marks are also gratefully acknowledged. This paper is published with the permission of the Executive Director of the British Geological Survey (Natural Environment Research Council).

\section{REFERENCES}

Aldiss D.T., Black M.G., Entwisle D.C., Page D.P., Terrington R.L. (2012). Benefits of a 3D geological model for major tunneling works: an example from Farringdon, east-central London, UK. Quarterly Journal of Engineering Geology and Hydrogeology 45(4), 405-414.

Allen D.J., Brewerton L.J., Coleby L.M., Gibbs B.R., Lewis M.A., MacDonald A.M., Wagstaff S.J., Williams A.T., Barker J.A., Bird M.J., Bloomfield J.P., Cheney C.S., Talbot J.C., Robinson V.K. (1997). The physical properties of major aquifers in England and Wales. British Geological Survey, Hydrogeology Series, Technical Report WD/97/34.

Barron A.J.M., Lott G.K., Riding J.B. (2012) Stratigraphical framework for the Middle Jurassic strata of Great Britain and the adjoining continental shelf. British Geological Survey report $\mathrm{RR} / 11 / 006$.

Campbell S.D., Merritt J.E., O Dochartaigh B. E., Mansour M., Hughes A.G., Fordyce F.M., Entwisle D.C., Monaghan A.A., Loughlin S.C. (2010) 3D geological models and their hydrogeological applications: supporting urban development: a case study in Glasgow-Clyde, UK. Zeitschrift der Deutschen Gesellschaft fur Geowissenschaften 161(2): 251-262.

CENTRE FOR ECOLOGY AND HYDROLOGY (2012). National River Flow Archive, Centre for Ecology and Hydrology (CEH). Online data access Sept 2012. http://www.ceh.ac.uk/ data/nrfa/data/time_series.html?39129

ENVIRONMENT AGENCY (2007). The Cotswolds Catchment Abstraction management Strategy Document, Environment Agency (EA), 2007. Online publication GETH1007BNME-E-E.

ENVIRONMENT AGENCY (2012). Climate change and river flows in the 2050s, Environment Agency (EA) Science Summary SC070079/SS1. Online publication SCHO1008BOSSE-P, Sept 2012.

Howard A. S., Hatton W., Reitsma F., Lawrie K.I.G. (2009). Developing a geoscience knowledge framework for a national geological survey organisation. Computers and Geosciences 35: $820-835$ 
James K., (2011). An overview of the Upper Thames Catchment Hydrogeology, and the Development of Neural Network Modelling for Baseflow Simulation. MSc Thesis. Cardiff University, UK.

Kaufmann O., Martin T. (2008). 3D geological modelling from boreholes, cross-sections and geological maps, application over former natural gas storages in coal mines. Computers and Geosciences 34(3): 278-290.

Kessler H., Mathers S.J., Sobisch H.G. (2009). The capture and dissemination of integrated 3D geospatial knowledge at the British Geological Survey using GSI3D software and methodology. Computers \& Geosciences 35: 1311-1321.

Marchant A.P., Banks V.J., Royse K., Quigley S.P., Wealthall G.P. (2011) An Initial Screening Tool for water resource contamination due to development in the Olympic Park 2012site, London. Environmental Earth Sciences 64(2). 483-495.

Maurice L., Barron A.J.M., Lewis M.A., Robins N.S. (2008). The geology and hydrogeology of the Jurassic limestones in the Stroud-Cirencester area with particular reference to the position of the groundwater divide. British Geological Survey Commissioned Report, CR/08/146.

Merritt J.E., Monaghan A.A., Entwisle D.C., Hughes A.G., Campbell S.D.G., Browne, M.A.E. (2007) 3D attributed models for addressing environmental and engineering geoscience problems in areas of urban regeneration: a case study in Glasgow, UK. First Break 25: 79-84.

Morgan-Jones M., Eggboro M.D. (1981). The Hydrogeochemistry of the Jurassic Limestones in Gloucestershire, England. Quarterly Journal of Engineering Geology 14(1): 25-39.

Neumann I., Brown S., Smedley P., Besien T. (2003). Baseline Report Series: 7. The Great and Inferior Oolite of the Cotswolds District. British Geological Survey report CR/03/202 N.

Parades C., (2012). Hydrogeological control of the river-aquifer interaction in the Cotswolds Limestone Aquifers, UK. MSc Thesis, University of Birmingham, UK.

Robins N.S., Rutter H.K., Dumpleton S., Peach D.W. (2005). The role of 3D visualisation as an analytical tool preparatory to numerical modeling. Journal of Hydrology 301(1-4), 287-295.

Royse K., Rutter H., Entwisle D. (2009) Property attribution of 3D geological models in the Thames Gateway, London: new ways of visualising geoscientific information. Bulletin of Engineering Geology and the Environment 68(1): 1-16.

Royse K., Kessler H., Robins N., Hughes A., Mathers, S. (2010). The use of 3D geological models in the development of the conceptual groundwater model. Zeitschrift der Deutschen Gesellschaft für Geowissenschaften, Schweizerbart 161(2), 237-249.

Rushton K.R., Owen M., Tomblinson L.M. (1992). The Water-Resources of the Great Oolite Aquifer in the Thames Basin, UK. Journal of Hydrology 132(1-4): 225-248.

Sumbler M.G, Barron A.J.M., Morigi A.N. (2000). Geology of the Cirencester district. Memoir of the British Geological Survey, Sheet 235 (England and Wales).

Wang L., Tye A., Hughes A. (2010) Riverine floodplain groundwater flow modelling: the case of Shelford (UK). Nottingham, UK, British Geological Survey, 28pp. Report IR/09/043. 